WOJCIECH STAROŃ

Wydział Operatorski i Realizacji TV Państwowa Wyższa Szkoła Filmowa, Telewizyjna i Teatralna im. Leona Schillera w Łodzi
Images vol. XXIII/no. 32

Poznań 2018 ISSN 1731-450X

\title{
Dokument a fabuła - refleksje, doświadczenia i metody pracy autora zdjęć filmowych
}

\begin{abstract}
Staroń Wojciech, Dokument a fabuła - refleksje, doświadczenia i metody pracy autora zdjęć filmowych [Documentary versus fiction - reflections, experiences and work methods of a director of photography]. „Images” vol. XXIII, no. 32. Poznań 2018. Adam Mickiewicz University Press. Pp. 121-134. ISSN 1731-450X. DOI 10.14746/i.2018.32.10.

As the very title of Wojciech Staroń, a cinematographer and film director's text "Documentary versus fiction - reflections, experiences and work methods of a director of photography" indicates, it is an attempt to analyse his own artistic achievements combined with a theoretical reflection on universal and fundamental issues such as understanding the truth in film, in reference to the distinction between the genres of fiction and documentary, or mentioned towards the end of the text, an issue of constructing a film protagonist and film narration in which the protagonist functions and is immersed. All these issues are analysed in a visual context, in reference to the construction of a film shot - the meaning of its contents and form and their combination which will present the subject matter in a few seconds of screen time. The films being analyzed among others are: Pod ochrona, Nagroda and Argentyńska lekcja (Argentinian Lesson).
\end{abstract}

KEYwORDs: documentary film, fiction film, film protagonist, art of cinematography, truth of film image, constructing a film shot

W tytule tekstu pojawia się przeciwstawienie filmu fabularnego i dokumentalnego. Zazwyczaj staram się unikać takiego rozróżnienia i wolę mówić po prostu „film”, bez podziału na rodzaj, gatunek, bez granic. Dlaczego?

Pod pojęciem „film” rozumiem z jednej strony obraz, który tworzy kamera filmowa, a z drugiej historię mającą strukturę - ciągłość, za którą podąża widz. Według takiej definicji wszelkie podziały na fabułę i dokument przestają mieć znaczenie. Wydają się sztucznie narzucone przez przemysł filmowy i krytyków.

Jedną z podstawowych cech dobrego filmu jest moment wejścia widza w świat wewnętrzny bohatera. Tutaj znaczenie może mieć, czy bohater jest stwarzany przez aktora, czy występuje przed kamerą człowiek ze swoim „realnym” życiem. Ale przecież w momencie „wejścia”, uwierzenia w emocje bohatera na ekranie, zapominamy, czy film jest grany przez aktorów, czy obserwujemy zdarzenia realne. Ten „magiczny” moment wejścia w opowieść, w historię innego człowieka,

\section{Świat wewnętrzny bohatera filmowego}

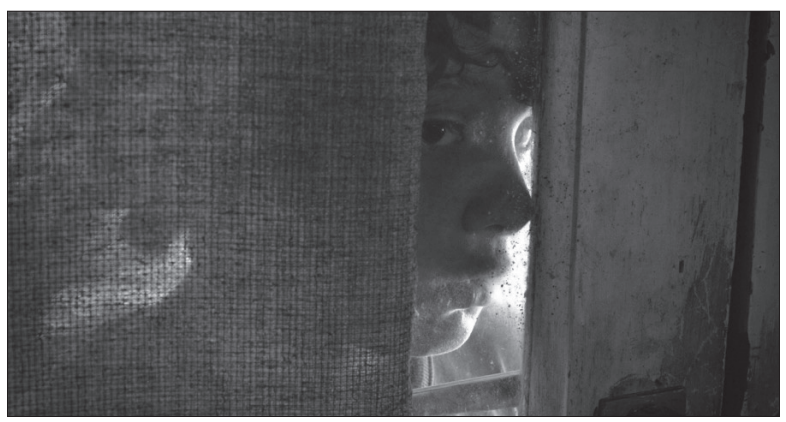

Il. 1. Pod ochrona, reż. Diego Lerman 
jest jednym $\mathrm{z}$ fundamentów sztuk dramatycznych, takich jak film, teatr czy literatura.

Co powoduje, że widz chce wejść w świat bohatera?

Dlaczego niektóre opowieści uwodzą nas tak mocno, a na inne pozostajemy obojętni? Jakimi środkami przekonać widza, by uwierzył w oglądaną historię fikcyjną, a jakimi w dokumentalną?

Dążenie do prawdy

Jednak nie uda nam się całkowicie uciec od definicji i teoretycznego rozgraniczenia na film fabularny i dokumentalny. Zderzymy

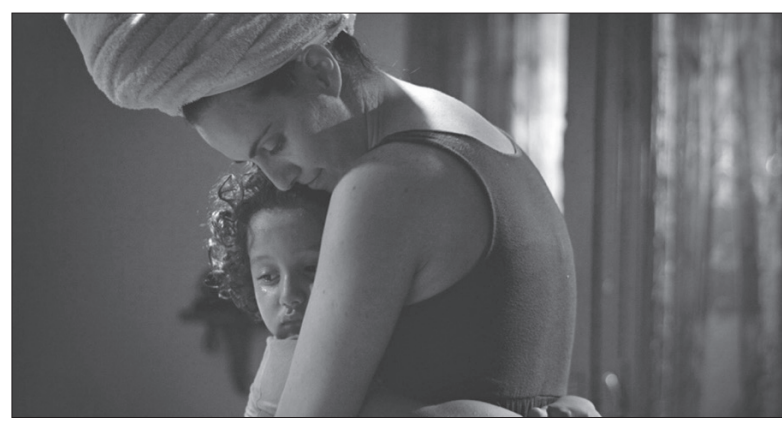

Il. 2. Pod ochrona, reż. Diego Lerman

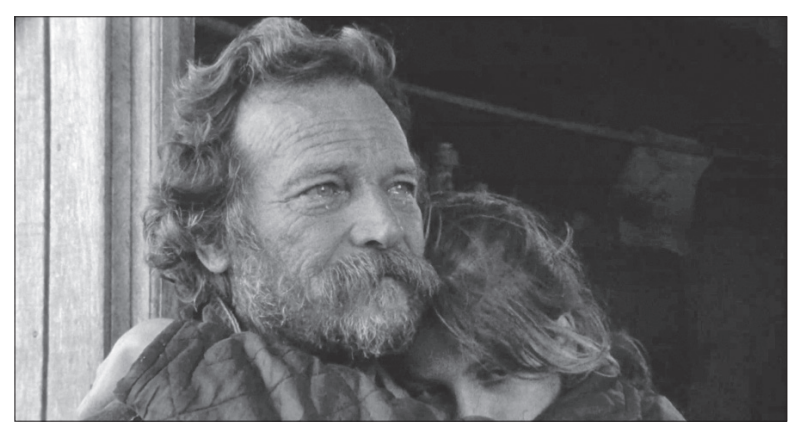

Il. 3. Argentyńska lekcja, reż. Wojciech Staroń

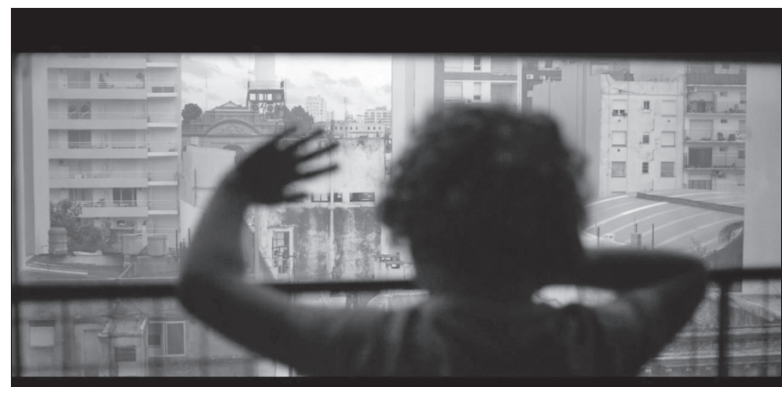

Il. 4. Pod ochrona, reż. Diego Lerman się chociażby z powszechnym utożsamianiem dokumentu i fabuły $z$ kinem fikcji i kinem faktu - z jednej strony kino $\mathrm{z}$ aktorami, scenografią, oparte na scenariuszu, inscenizacji, klasycznej dramaturgii, $\mathrm{z}$ drugiej strony kino $\mathrm{z}$ możliwą afabularną konstrukcją, z niezawodowymi aktorami i niemal bez ingerencji w prezentowaną rzeczywistość. Oczywiście, można taki porządek łatwo zburzyć, wystarczy sięgnąć do historii kina - na przykład z jednej strony pierwsze filmy Krzysztofa Kieślowskiego i Agnieszki Holland czy braci Dardenne, bliskie metodom dokumentalnym, $z$ drugiej kino dokumentalne polskich kreacjonistów z Bogdanem Dziworskim i Wojciechem Wiszniewskim na czele. Moim zdaniem podstawową zasadą kina - i fabularnego, i dokumentalnego - jest dążenie do prawdy. Z założenia bliżej prawdy powinno być kino dokumentalne - bo to kino faktu, kino bezpośrednio czerpiące $\mathrm{z}$ rzeczywistości, ale wiemy, że kino chociażby Andrieja Tarkowskiego czy Ingmara Bergmana jest prawdziwsze niż niejeden dokument. Czym w takim razie jest prawda filmowa? Co powinno być podstawowym wyznacznikiem filmu? Z czego powinien on czerpać?

Jerzy Wójcik napisał: „filmy robi się z tego świata, który się nosi w sobie. Można dać tylko to, co się ma”'[1]. Może jest to jakiś szczególny rodzaj prawdy przefiltrowanej przez subiektywne ja, prawda wewnętrzna, obiektywna (przecież są „udawane” dokumenty)? Jakie są najważniejsze wartości w kinie, co może ono pokazać, o czym opowiadać?

Przecież Pod ochroną i Nagroda, a z drugiej strony Argentyńska lekcja, to nie tylko hi-

[1] J. Wójcik, Labirynt światła, Warszawa 2006, s. 11. 
storie, która mają być bliskie faktom; one mają być bliskie emocjom, psychice i uczuciom dziecka, u którego budzi się jakaś świadomość.

W kinie, podobnie jak w literaturze, rodzaje się zacierają. Czytając reportaże Hanny Krall, nie pytam, czy to „fabuła”, czy „dokument”. Ona tak filmowo pisze, dotyka od razu najważniejszych spraw. Nie ma tam żadnych „boków”, zbędnych opisów. A kiedy są, to bardzo potrzebne - tworzące drugi, trzeci plan życia bohatera. W jednej z rozmów Hanna Krall powiedziała:

Reportaż jest zwykle o świecie zewnętrznym, prawda? Ale czasem reporterowi uda się ów świat przepuścić przez siebie. No, można tego nie robić, kiedy się pisze o sprawach, a nie o ludziach. Wtedy wystarczy zewnętrzność. Ale kiedy reportaż ma być czymś ważnym, trzeba go przepuścić przez siebie jak przez tunel. Nie ma innej drogi, wokół tego tunelu nie ma objazdu. I myślę, że o tym, czy reportaż ma stać się czymś ważnym, decyduje właśnie: ile się doda samego siebie do zewnętrznego, cudzego świata. [...] Krytycy, historycy literatury nie szukają jednak znaczeń w literaturze faktu. Uważają opisane tam zdarzenia za jednorazowe. Fakty znaczą, ile znaczą. Z wielką powagą traktują tylko literaturę piękną, w której doszukują się symboli i metafor. Nie rozumiem, dlaczego bardziej nośny jest dla nich los wymyślony niż autentyczny, fikcyjne, a nie prawdziwe zdarzenia. W tym, co opisuje literatura faktu, nie szuka się żadnych związków przyczynowych, a mnie się wydaje, że to ona jest głównym źródłem poznania, że to w miejscach zetknięć zdarzeń, ludzi, faktów najwyraźniej przejawia się - nie chcę używać wielkich słów - Opatrzność, Bóg, Wielki Scenarzysta. Postawa krytyków jest dla mnie wyrazem nonszalancji wobec życia. [...] Myślę, że ludzie są zmęczeni drugorzędnością i zmyśleniem. Wszystko co widzimy w serialach telewizyjnych, wideoklipach, filmach grozy - jest na niby. Strach na niby, śmierć na niby. A w historiach, które opowiadam, jest prawdziwa śmierć, prawdziwy strach, prawdzi-

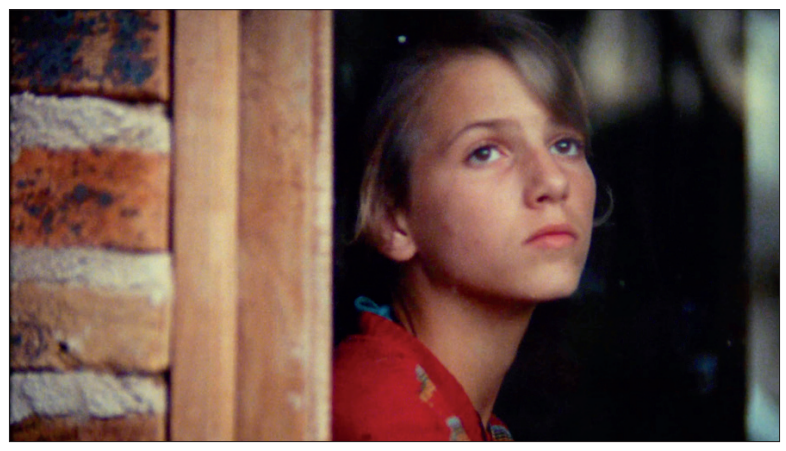
wa odwaga. Może i czytelnicy mają dość wymyślonych historii, prostych prawd, może chcą usłyszeć pytania, na które nie ma odpowiedzi[2].

Myśląc o metodzie pracy, która jest mi bliska i która łączy w sobie oba gatunki filmowe, myślę o obserwacji, która czasami jest nazywana „obserwacją dokumentalną". Poprzez obserwację powszechnie rozumie się sposób pracy kamery, który nie uprzedza ruchów filmowanych ludzi i obiektów. Wynika to $\mathrm{z}$ tego, że operator nie wie wszystkiego, co się będzie działo przed kamerą. W tej metodzie mamy do dyspozycji nasze emocjonalne zaangażowanie w proces filmowania, czujność, spostrzegawczość i może przede wszystkim - intuicję. Czasami prowadzi to do bardzo ekspresyjnej i zaangażowanej pracy kamery, na przykład dynamiczna kamera $\mathrm{z}$ ręki łapiąca najgorętsze momenty filmowanej sytuacji, a czasami reakcją będzie spokój i dystans, na

Il. 5. Argentyńska lekcja, reż. Wojciech Staroń

\section{Obserwacja jako spotkanie}




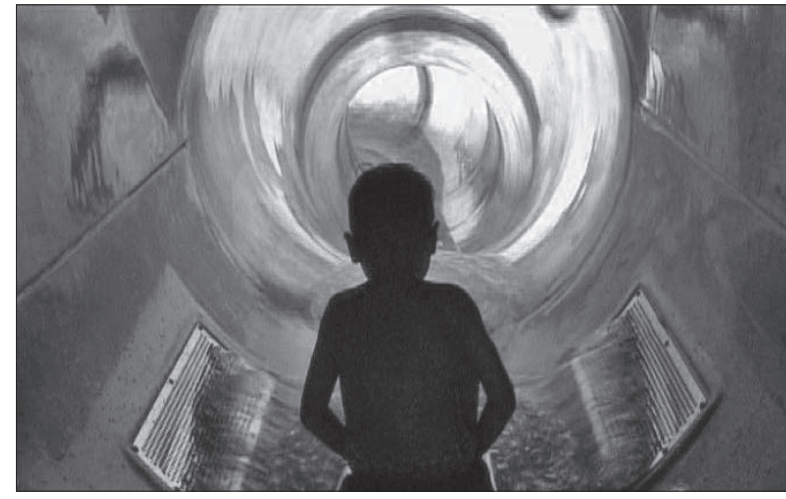

przykład statyczna kamera niezależnie od ruchów i rozwoju napięcia w kadrze. Obserwacja może mieć na celu zdanie jak najlepszej relacji z wydarzeń - skrajnym przykładem jest chociażby filmowa relacja z meczu piłkarskiego, ale akt filmowania może również stać się swoistą kontemplacją płynącego czasu. Osobiście uważam, że obserwacja jest czymś więcej niż tylko zdawaniem relacji - to specyficzny stan ducha. Ten moment wynika $\mathrm{z}$ metafizyki - z refleksji nad otaczającym nas światem, wtopieniem się

Il. 6. Na chwile, reż. Wojciech Staroń w rzeczywistość. Operator koncentruje się i uważnie czeka na to, co się wydarzy przed obiektywem: czeka i obserwuje, jest widzem, ale też uczestnikiem wydarzeń - filmując i jednocześnie wchodząc w sposób błyskawiczny w relację z tym, co się dzieje przed nim. Ten moment określiłbym również jako s p otka ni e. Tak jak w spotkaniu dwojga ludzi, gdy patrzymy na siebie i słuchamy się, dochodzi do wzajemnej wymiany, operator powinien wsłuchać się w filmowanego człowieka, $\mathrm{w}$ jego gesty, spojrzenia, jego stan wewnętrzny, a także w otoczenie: światło, architekturę, pejzaż, porę dnia, przyrodę, żywioły. Dopiero całkowite zatopienie się w świecie, który mamy przed kamerą, pozwoli nam w ujęciu wybrać właściwą kompozycję, sposób kadrowania, ruchu kamery, optykę i wyrazić istotę sprawy. I nie chodzi tu o realizm, o dokumentalny weryzm, o unikanie interpretacji.

Bardzo istotny jest wybór obiektywów i odległości od filmowanego człowieka bądź obiektu. W ten sposób określamy nasz stosunek do filmowanej osoby i wydarzenia. Zupełnie inną temperaturę i inny wyraz będzie miał portret sfilmowany teleobiektywem $200 \mathrm{~mm}$ z odległości pięciu metrów niż taki sam portret sfilmowany obiektywem szerokokątnym 25 mm z odległości pół metra. Podczas obserwacji niezwykle ważne są decyzje, które operator podejmuje. Wynikają one z otwartości i gotowości na to, co się wydarza. Tak jak w fotografii, panuje tu też zasada decydującego momentu, stąd potrzeba wielkiej koncentracji. Proces wyboru - eliminacji zbędnych elementów w kadrze - wydaje mi się zresztą kluczowym procesem budowania opowieści filmowej. $\mathrm{Na}$ każdym etapie - od scenariusza po montaż i postprodukcję.

Wiele lat temu, na zdjęciach do filmu dokumentalnego Jerzego Śladkowskiego My American Family, w wiosce na południu Włoch, zostałem poproszony przez reżysera o trochę obrazów życia wsi. Zacząłem chodzić i patrzeć na senną i „bezludną” wioskę. Widzę wszystko i nic, wszędzie można sfilmować przeciętnie przyzwoite ujęcie. Ale jak rozszyfrować ducha tego miejsca? Zdałem sobie sprawę, że najciekawsze rzeczy zaczynają się dziać, gdy zaczaiłem się w jednym miejscu i czekałem. Szukałem więc takiego miejsca, w którym potencjalnie może wydarzyć się minihistoria. W pewnym momencie, gdzieś w oddali, za drzewami dostrzegłem rękę machającą co pewien czas szmatą. Przybliżyłem się z kamerą i gdy ustawiłem kadr, stałem się świadkiem swo- 
istego misterium. Wszedłem w rytm starszej kobiety siedzącej na progu domu i odganiającej muchy. Spędziłem tam następne trzy godziny, ponieważ scenariusz pisał się sam. Wnikając w to miejsce, zaobserwowałem cały kosmos. Pojawiła się siostra, potem kury, potem sąsiadka, potem mąż. Finał był taki, że zaczęli rozmawiać o mnie, dziwili się, co ciekawego tu można filmować (?) Sekwencja stała się refrenem filmu, a ich pytanie o sens mojej pracy reżyser umieścił jako finałową scenę.

Myślę, że obserwacja filmowa jest jakby pierwotnym narzędziem filmu, może być punktem wyjścia do opowiedzenia każdej historii. W literaturze najbliższe mojemu rozumieniu obserwacji filmowej może być japońskie haiku. Wydaje mi się, że do każdego ujęcia w swoich filmach starałem się podchodzić jak do osobnych miniutworów. Zresztą takiej dyscypliny wewnętrznej wymagała od operatorów praca na taśmie filmowej. Każde ujęcie powinno mieć swój wewnętrzny przebieg: początek, rozwój i koniec. Operator sam opowiadał w ujęciu jakby minihistorię. A potem, dokładając następne ujęcia, powstawała ciągłość. Pamiętam, jak materiał do mojego pierwszego filmu Syberyj-
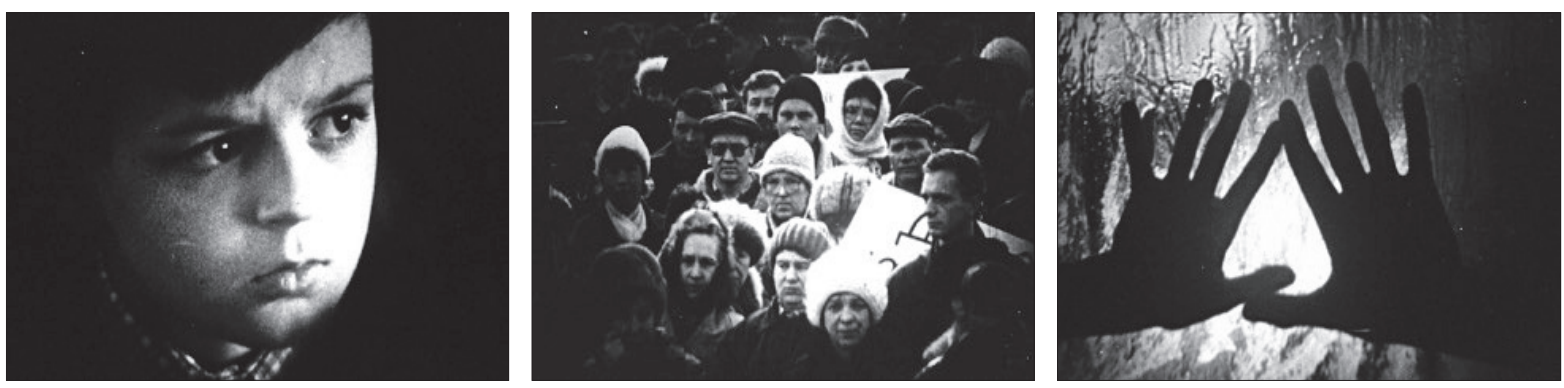

ska lekcja został pocięty w montażowni przez Zbyszka Osińskiego na pojedyncze ujęcia. Każde z nich wisiało na swoim gwoździu-wieszaku. Można było je wziąć do ręki i pod światło obejrzeć. Praca w montażowni na pozytywie - na tak zwanej kopii roboczej filmu - należała do najprzyjemniejszych momentów. Każde ujęcie było na wagę złota. Szum przesuwanej taśmy zastępował dźwięk filmowy, historia musiała opowiadać się sama poprzez obrazy: bez dialogów i muzyki. Osiński, montażysta wszystkich moich filmów, uczył mnie syntezy opowiadania, wyciągania esencji i tego, co naprawdę jest istotne dla historii.

W polskim filmie dokumentalnym jest się czym inspirować. To fenomen światowy, żeby tyle dobrego powstawało w jednym miejscu przez tak długi czas. Pamiętam, jak silne wrażenie zrobiły kiedyś na mnie filmy Pierwsza miłość Krzysztofa Kieślowskiego i Nienormalni Jacka Bławuta, obejrzane w liceum. Oba opowiadają historie prawdziwych ludzi, ale przecież najważniejsze w nich jest to, jak te opowieści

Il. 7. Argentyńska lekcja, reż. Wojciech Staroń
Il. 8. Syberyjska lekcja, reż. Wojciech Staroń

Filmowiec a prawda 
zostały przefiltrowane, przeżyte przez reżyserów, co z życia bohaterów zaczerpnęli do filmu i jak skonstruowali swoją własną opowieść. W każdym z nich odczuwamy obecność autorów, poznajemy ich wrażliwość, ich sposób patrzenia na świat. Wyrazistym przykładem filmu dokumentalnego bazującego na realnych wydarzeniach, ale będącym czystą filmową ekspresją, jest Hokej w reżyserii Bohdana Dziworskiego, ze zdjęciami Ryszarda Lenczewskiego i montażem Agnieszki Bojanowskiej. Tam relacja $\mathrm{z}$ widowiska sportowego staje się studium ludzkich emocji. Zdjęcia dokumentalne mieszają się w perfekcyjny sposób $\mathrm{z}$ inscenizacjami. Wiemy, że samo wydarzenie schodzi na drugi plan, a liczy się to, jak autorzy na to patrzą, co dostrzegają w obserwowanej rzeczywistości. Wydarzenia realne są jakby partyturą lub jazzowym standardem, który operator jak instrumentalista zaczyna rozwijać i interpretować na swój indywidualny sposób. Tak jak słuchając muzyki, poznajemy nie tylko kompozytora, ale może przede wszystkim wykonawcę, który „wkłada” w wykonanie siebie, chyba że udaje kogoś innego i wtedy czujemy fałsz. Tak samo w filmie obnaża się przed nami przede wszystkim filmowiec.

Józef Robakowski w eseju Kino własne pisze:

Kino własne - już przez swoje istnienie jest faktem, mimo że faktów z życia nie musi dotyczyć. Nie znaczy to, że zajmuje się rejestracją natury, bowiem ma ją wliczoną w swój sens istnienia. Posiada więc wszelkie możliwości być kinem nadal, ale kinem własnym - czyli bezpośrednią projekcją myśli filmującego. Zwolnione od wszystkich mód i prawideł estetycznych oraz ustalonych kodyfikacji językowych staje blisko życia filmującego. Można powiedzieć, że jest jego miłością i pasją, ale też często krzywym zwierciadłem. Filmujemy więc wszystko, a okaże się, że filmujemy samego siebie. Taki sfilmowany filmujący człowiek żyje dopiero na ekranie i ma podobną do ciebie posturę, ale inny charakter i osobowość. To niezmiernie interesujące, że przez ekran można polemizować samemu z sobą[3].

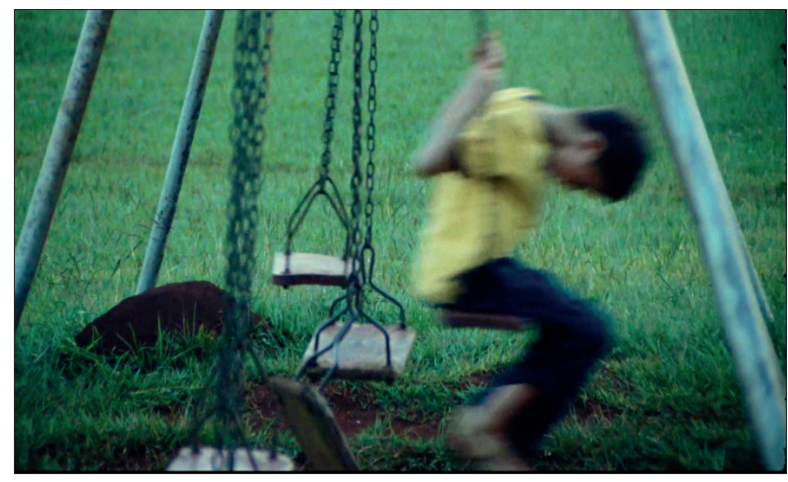

Znakomita montażystka Agnieszka Bojanowska uważa, że ekran odbija to, co w momencie robienia zdjęć czuł operator, o czym myślał, czym miał zajętą głowę, czy obchodziło go to, co filmował, a jeśli tak, to od razu widać, jaki miał do tego stosunek: obojętność czy zaciekawienie? A może fascynacja? Może strach? Nieśmiałość czy pewność siebie? Od razu odczytywała, co operator robił przed zdjęciami, czy był zmęczony, czy umiał wchodzić "na całego" w temat filmowany. Dla niej było

Il. 9. Argentyńska lekcja, reż. Wojciech Staroń to niezwykle czytelne. Patrząc tylko na materiał, potrafiła nakrzyczeć na operatora za to, że się obijał na zdjęciach, że się nie wyspał lub upił poprzedniej nocy. Ekran jest swoistym, zaklętym kodem tych wszystkich stanów. Odbija duszę operatora i zatrzymuje w czasie jego myśli.

[3] J. Robakowski, Kino własne, 1981; <www.robakowski.eu/p27.html>. 
Zdecydowanie wyczuwają to również widzowie, nieświadomi warsztatu i kuchni filmowej. Prawdę i fałsz odbierają instynktownie, podświadomie, i ta ocena wiarygodności jest jedną z podstawowych miar, czy film był dobry, czy nie. Wydaje się, że prawda wypowiedzi jest wyłapywana w sposób naturalny przez ludzi wrażliwych na drugiego człowieka i jego historię. Marian Marzyński, montując swoje filmy w WFD na Chełmskiej w Warszawie, z okna montażowni, które wychodziło na ulicę, wołał przypadkowych przechodniów i zapraszał do montażowni, by obejrzeli pierwszy układ montażowy filmu. Bacznie ich obserwował podczas projekcji i słuchał komentarzy. Inna reżyserka zapraszała na pierwsze pokazy swoich filmów licealistów, bo twierdziła, że to właśnie oni są najbardziej wymagający i wyczuleni na najmniejszy nawet fałsz.

Raymond Depardon, francuski reżyser i fotograf, pisał:

Nie wiem, czy fotografia jest dokumentem, czy fikcją, natomiast bardzo dobrze oddzielam w kinie dokument od fikcji. Uwielbiam żeglować między tymi dwiema przestrzeniami [...]. Nakręciłem wiele dokumentów i trochę filmów fabularnych. Bardzo lubię zbliżać się do dokumentu, kiedy kręcę film fabularny, a moje filmy dokumentalne są czasami bardzo bliskie fabule, na przykład gdy ustawiam się pod pewnym kątem i decyduję się nie zmieniać kadru i nie ruszać kamery. Errance jest fikcją czy dokumentem? Na początku jest wiele elementów, które powodują, że myślimy, że to fabuła. Jest chęć kalkulowania, reżyserowania, a z drugiej strony pojawia się bliska dokumentowi improwizacja.

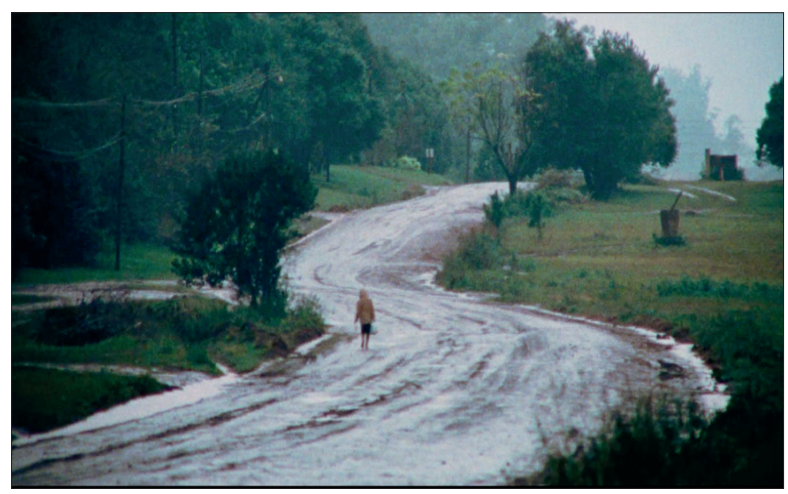
Myślę, że nie jestem dokumentalistą, bo nawet nie podpisuję, nie oznaczam miejsc, w których fotografuję pejzaże i nie piszę nawet, w jakim to było kraju. Daję do zobaczenia obraz, który nie

Il. 10. Argentyńska lekcja, reż. Wojciech Staroń jest informacyjny, ale jest abstrakcyjny - nie ma w nim informacji o temacie. Ale $\mathrm{z}$ drugiej strony nie jestem całkowicie $\mathrm{w}$ fikcji, ponieważ to nie są wymyślone, wykreowane światy. Jest za tym rzeczywistość realna, jestem ja jako operator, fotograf, człowiek z konkretnej kultury zachodniej, poszukujący[4].

I jak stwierdza dalej:

Fotograf jest reżyserem nawet gdy fotografuje rzeczywistość. Przez długi czas nie zdawałem sobie z tego sprawy, że zawsze reżyseruję, myślałem, że wystarczy być świadkiem realnego wydarzenia, lecz tak naprawdę i tak byłem reżyserem, byłem kimś, kto ingerował w rzeczywistość i bez zdawania sobie sprawy byłem bardziej w fabule niż myślałem. [...] Errance a priori nie miało żadnego przesłania, żadnej tezy. Przekaz odpowiada zawsze na pytanie jakie miałem założenie przed wyjazdem i jak ono się

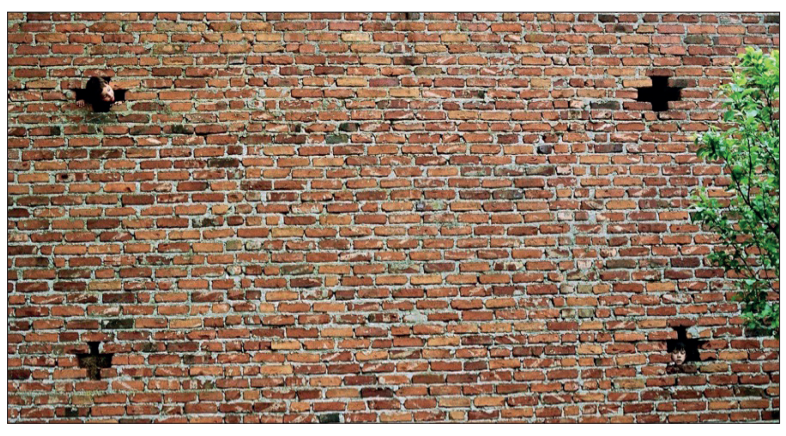

Il. 11. Na chwile, reż. Wojciech Staroń

[4] R. Depardon, Errance, Seul 2004, s. 24. 
zmieniało w trakcie pracy, robienia zdjęć. Z jednej strony odklejałem się od zamierzonej historii, ponieważ nie chciałem jeździć po świecie i opowiadać o biedzie, o ludziach bogatych, o Indianach i nie chciałem interweniować $\mathrm{w}$ ten świat. Nie było więc przekazu, tematu, było jedynie zadawanie pytań - poszukiwanie tego, w jaki sposób można zobaczyć czysty stan danej rzeczywistości. Nie chcę nikogo oskarżać i nie chcę nic wyrażać, pragnę pokazywać mój sposób patrzenia na pewną część świata w pewnym momencie czasu[5].

\section{Czy istnieje definicja filmu dokumentalnego?}

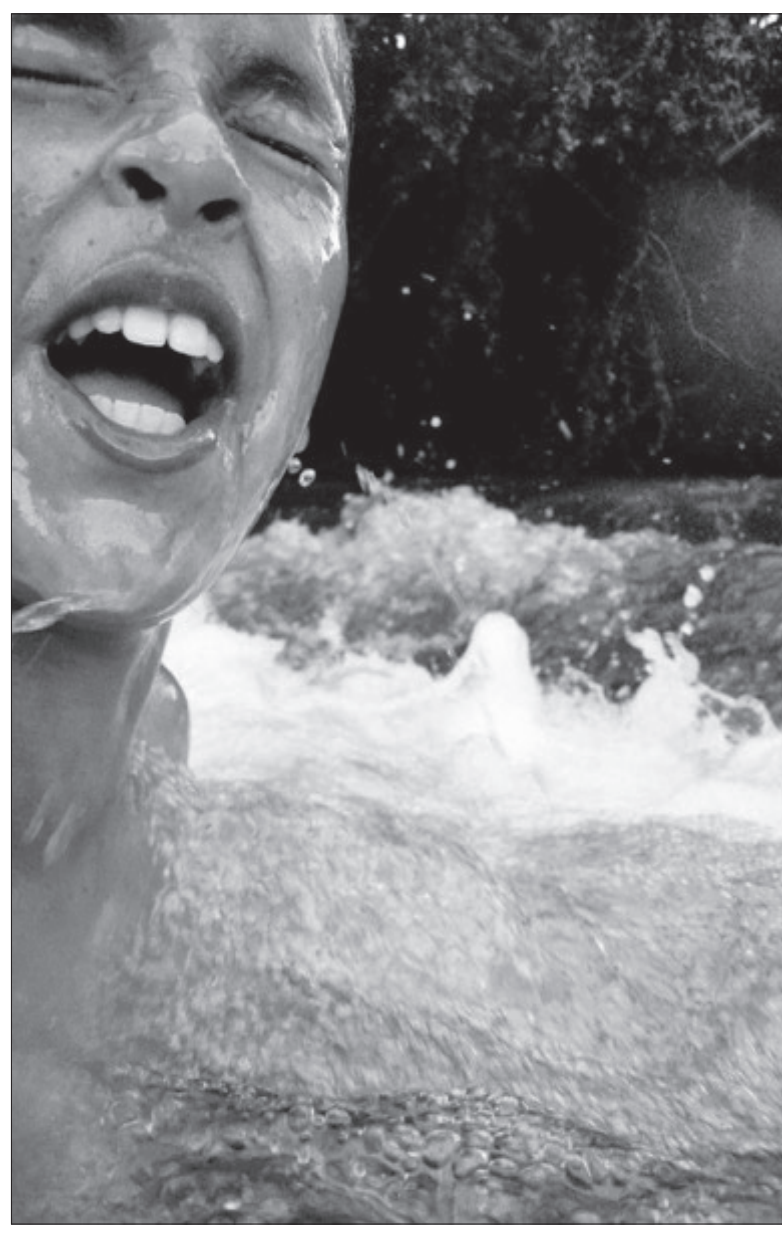

W roku 1948 na Światowym Kongresie Dokumentalistów ogłoszono definicję filmu dokumentalnego. Zgodnie z jej brzmieniem:

film dokumentalny jest realistyczną metodą rejestracji rzeczywistych zdarzeń, które zostają sfilmowane „na gorąco”, poddane interpretacji (kronika filmowa), bądź rzetelnie zrekonstruowane. Współcześnie do głównych jego wyróżników zalicza się ukazywanie rzeczywistości uprzednio niezaaranżowanej, z uwzględnieniem rządzących nią naturalnych reguł, czyli na przykład jej związków czasoprzestrzennych i przyczynowo-skutkowych. Wyklucza to uznanie za dokument choćby najrzetelniejszą metodę rekonstrukcji zdarzeń[6].

Dzisiaj nie trzeba komentarza, by dostrzec, jak archaiczna jest ta definicja. Film dokumentalny stał się polem do poszukiwań nowego języka obrazu, zaczął burzyć klasyczne narracje, a kreacja twórcza zastąpiła dążenie do obiektywizmu.

Jednak, by oprzeć się na czymś teoretycznym, chciałbym przywołać refleksje Wojciecha Wiszniewskiego, który skonstruował bardzo obszerną definicję kina dokumentalnego. Jest mi ona dużo bliższa. Według Wiszniewskiego film dokumentalny to taki, który „wiernie” odzwierciedla rzeczywistość, przy czym możemy mieć do czynienia z wiernością rejestracyjną, opisową, wiernością w oddaniu nastroju, z wiernością tradycji i wiernością epoce[7]. Jednak według tej definicji można w poczet dokumentów zaliczyć chociażby fabularny Boyhood w reżyserii Richarda Linklatera, w którym mamy do czynienia z dokumentalną wiernością zapisu zmian fizycznych bohaterów - film był kręcony z tymi samymi aktorami przez 12 lat i na ekranie w ciągu dwóch godzin obserwujemy proces ich starzenia się. Przecież zapis ich przemiany jest jak najbardziej wierny,

[5] Ibidem, s. 26.

[6] A. Kołodyński, Tropami filmowej prawdy, Warszawa 1981, s. 28-29.
[7] W. Wiszniewski, Film jako instrument oddziaływania społecznego, 1975 (praca magisterska: Archiwum PWSFTviT w Łodzi), s. 10. 
autentyczny i jakby mimochodem dokumentalny. To najcenniejsze, co z tego filmu płynie: swoista refleksja nad przemijającym w sposób fizyczny życiem. Prawda niezależna od filmu i historii scenariuszowej - obserwacja dokumentalna stworzyła dramaturgię, zbudowała suspens i dzięki temu również został skonstruowany wewnętrzny rytm filmu. Można wysnuć wniosek, że film dokumentalny nie podda się żadnym definicjom i jest w pewnym sensie integralną cechą każdego aktu filmowania.

Do definicji Wiszniewskiego dodałbym jeszcze jedną bardzo istotną dokumentalną „wierność” - wierność przeżyciom i autentycznym emocjom bohatera. Według mnie ten czynnik w zdecydowany sposób zawsze stanowił, czy film określamy jako dokument, czy fabułę. Chodzi o to, czy to reżyser sam kreuje, wymyśla bądź ubarwia dramat bohatera - jego emocje, stany i przeżycia, czy jest wierny temu, co dzieje się naprawdę w życiu filmowanej osoby. Przez ostatnie dwadzieścia kilka lat stałem za kamerą, filmując fascynujące losy, obserwując małe i duże ludzkie dramaty. Zawsze wiązało się to $\mathrm{z}$ procesem poznawania tych ludzi, „wchodzeniem” w ich życie, zdobywaniem ich zaufania. $\mathrm{Z}$ jednej strony jako filmowiec wiedziałem, że, aby stworzyć obraz filmowy, muszę złapać emocje, te trudne, przełomowe momenty w życiu, napięte relacje. $Z$ drugiej strony, stojąc za kamerą, kręcąc i reżyserując lub mając u boku reżysera, czułem, że mam przewagę nad moimi bohaterami, że zawsze kamerą mogłem im pomóc lub zaszkodzić, pokazać ich los w sposób naturalistyczny lub przerysowany. Co więcej, narzędzie, jakim jest kamera i stół montażowy, daje poczucie możliwości wykreowania i odrealnienia autentycznych zdarzeń i dramatów, wyolbrzymienia lub osłabienia przeżywanych przez bohaterów emocji, a nawet wykreowania emocji, które naprawdę nie zaistniały. Obecność reżysera zawsze daje poczucie, że życie bohaterów dokumentalnych też można „wyreżyserować”. Ta przewaga i wolność w interpretacji tego, co widzimy, zmusza nas do odpowiedzialności za to, jak opiszemy drugiego człowieka. Każda z interpretacji, jaką jest moment filmowania czyjegoś życia, jest kreacją, czyli reżyserią nowej rzeczywistości. Jednak w moim pojęciu w dokumencie powinniśmy wszystkimi środkami dążyć do ukazania tych najbardziej autentycznych przeżyć. W tym tkwi ogromna rola operatora, który zwykle jest fizycznie najbliżej bohaterów i siłą rzeczy ma olbrzymi wpływ na przebieg emocjonalny w każdej filmowanej sytuacji - czy zdąży, czy nie, czy dostrzeże istotę sprawy, czy jej nie zauważy, czy poruszy go dramat przed kamerą, czy pozostanie obojętny, i w końcu - czy operator stworzy warunki, by bohater czuł się bezpiecznie i naturalnie przed kamerą. Operator ma również zasadniczy wpływ na to, co kamerą pokaże, a co ukryje, co zaakcentuje, a co „unieważni” - tak więc ten moment kreacji w dokumencie powinien podlegać szczególnej trosce i uwadze, koncentracji i oddaniu się bohaterom. Jest to praca bez dubli, bez powtórek i bez wiedzy, co się wydarzy przed kamerą za chwilę. Dla mnie te elementy stanowią sed- 


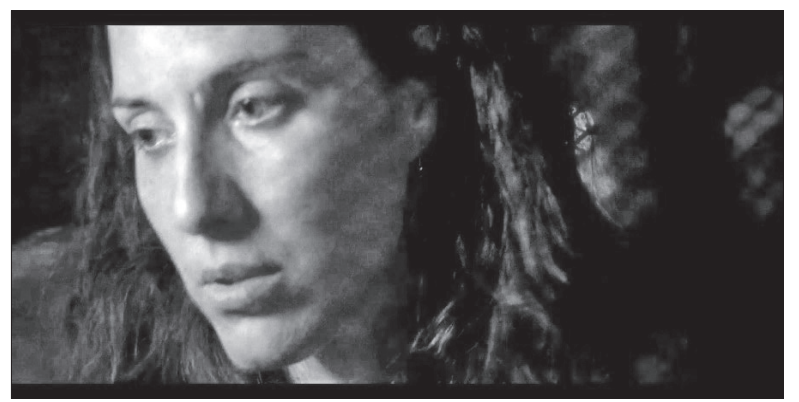

no pracy operatora w dokumencie, inspirują i wywołują emocje: zaciekawienie, niepokój, radość, napięcie oczekiwania, doświadczenie przeżywania życia tu i teraz, i to jest fenomen kreacji w filmie dokumentalnym.

Bardzo ciekawym przykładem uchwycenia prawdy emocjonalnej i stworzeniem niezwykle wiarygodnej opowieści filmowej balansującej na granicy gatunku jest film Pawła

Il. 13. Pod ochrona, reż. Diego Lerman
Łozińskiego Nawet nie wiesz, jak bardzo cię kocham. Treścią filmu jest zapis terapii - oglądamy pięć sesji terapeutycznych, w których uczestniczy terapeuta i dwie kobiety: matka i córka. Mimo że bohaterki filmu odgrywają role, które im reżyser zaproponował, to faktycznie w swoim życiu każda $\mathrm{z}$ nich przeżywa podobny dramat. Jak w psychodramie wchodzą w swoje role niezwykle autentycznie, sięgają do siebie, swojego życia i są prawdziwe. Czy to jest film dokumentalny? Jak najbardziej!

Mamy też filmy fabularne, posługujące się obserwacją dokumentalną. Choćby wspomnieć o niektórych z nich: Kes Kena Loacha ze zdjęciami Chrisa Mengesa, polskie filmy Krzysztofa Kieślowskiego i Agnieszki Holland ze zdjęciami Jacka Petryckiego i Witolda Stoka, po Last resort czy Lato miłości Pawła Pawlikowskiego ze zdjęciami Ryszarda Lenczewskiego. Operatorzy i reżyserzy wszystkich tych filmów mają swoje korzenie w filmie dokumentalnym. Oglądając Last resort, wielokrotnie gubimy poczucie, że jest to fikcja fabularna. Historia głównej bohaterki - tułaczka emigrantki z dzieckiem w obcym państwie - właściwie świetnie nadawałaby się również na film dokumentalny. Kamera Lenczewskiego chwyta ulotne emocje, co do których mamy wrażenie, że nie są do wyreżyserowania, można je tylko czujnym i wrażliwym okiem podpatrzeć. Operator w takim filmie ma niezwykłą rolę, ponieważ staje się współreżyserem, często decydującym, co i jak pokazać kamerą. W tym filmie jest mało ingerencji w scenografię, występują autentyczne postaci grające samych siebie, jak na przykład reżyser filmów porno, namówiony przez Pawlikowskiego do wzięcia udziału w filmie.

„Sztandarowym przykładem na podejście człowieka, który zaczynał od dokumentu, jest Krzysztof Kieślowski” - mówi Jacek Petrycki, operator jego wielu filmów zarówno dokumentalnych, jak i fabularnych. I stwierdza dalej:

Gdy zaczęliśmy robić pierwsze filmy fabularne, to uważaliśmy, że muszą one wyglądać jak dokument, muszą pod względem stylistycznym i w braku kreacji fabularnej udawać rzeczywistość w sposób absolutnie imitujący. Mieliśmy wtedy takie zasady, i razem z Krzyśkiem, i z Agnieszką Holland, pierwsze filmy robiliśmy jednym obiektywem - trzydziestką piątką, bo zbadaliśmy i przeczytaliśmy w mądrych książkach, że to jest obiektyw najbardziej zbliżony do kąta widzenia oka ludzkiego i tylko tak można fotografować, a każde odstępstwo w którąkolwiek stronę, to już jest kreacja. To był ten pierwszy okres, w którym były dwie grupy operatorów: Witold 
Stok, Zbyszek Wichłacz, ja - myśmy wyszli $\mathrm{z}$ dokumentu. Ja wtedy filmy fabularne robiłem z lojalności i przyjaźni, bo wydawało mi się, że mnie to w ogóle nie interesuje. A z drugiej strony byli: Edward Kłosiński, Witek Adamek, Sławek Idziak - typowi fabularzyści. Mieliśmy bardzo wyraźnie zasady: wnętrza tylko naturalne, jeśli z jakichś produkcyjnych powodów musieliśmy zaadoptować jakieś wnętrze, to przychodziliśmy całą ekipą, wylewaliśmy kawę, brudziliśmy, żeby urealnić, i mieliśmy absolutną zasadę - żadnych amerykańskich numerów

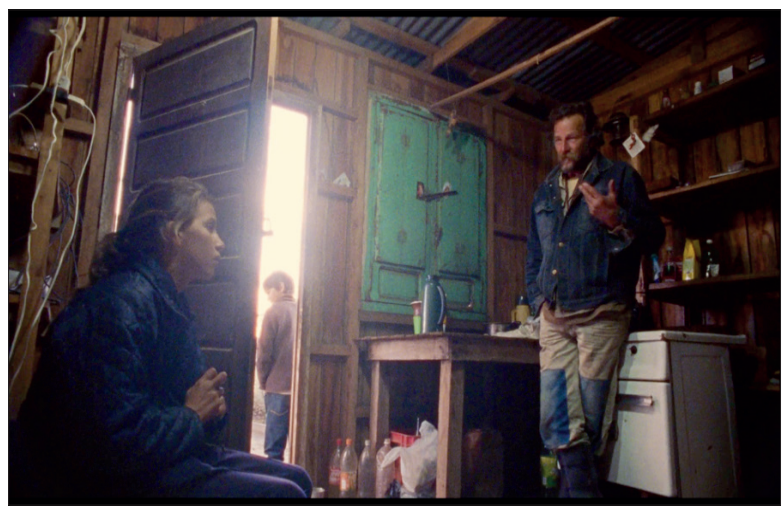
typu kamera przejeżdża przez ścianę. Jeśli scenograf chciał mi przesunąć jakąś ściankę albo mebel, ja mu mówiłem, że w żadnym wypadku - przecież kamera nigdy by tam nie stanęła. [...] Jest oczywistą rzeczą, że jak robisz film fabularny, to masz tę historię napisaną i może być różnie: werystycznie albo bardzo kreacyjnie. Natomiast w dokumencie, w bardzo wielu wypadkach jest taka sytuacja, że ta historia mi się rodzi dopiero w głowie i to przenosi się na proces filmowania, bo się staram tę historie wydobyć. Zobaczyć coś takiego, co spowoduje, że ten film będzie wciągał. Zawsze mówię, że trzeba walczyć o wieloplanową kompozycję, żeby albo tło, albo pierwszy plan, w jakiś sposób komentowały to, w jakiej sytuacji znajdują się bohaterowie. Oczywiście takie elementy w fabule też są, ale w dokumencie one się bardzo często rodzą po prostu na planie. I szkoła PRL-u była pod tym względem bardzo skuteczna, ponieważ filmowaliśmy tak, że często używaliśmy informacyjnych rzeczy w kadrze, które miały nam dopowiadać bohatera i często sama kompozycja powodowała, że nim człowiek coś powiedział, to my już wiemy, kim on jest. W ten sposób, $\mathrm{w}$ dokumencie, operator $\mathrm{w}$ większym stopniu przyjmuje rolę reżysera, niż w filmie fabularnym, i dobry reżyser, to po pierwsze akceptuje, a po drugie współpracuje. Uwielbiam takich reżyserów, z którymi pracuję i nagle słyszę szept do ucha: «w lewo», bo widzimy coś, co może kompletnie zmienić kierunek naszej historii[8] -

kończy swoją wypowiedź Jacek Petrycki.

Za Marcelem Łozińskim możemy zapytać: jaka jest różnica między prawdą a wiarygodnością w filmie?

To bardzo ciekawe pytanie nasuwa taką refleksję: film fabularny, żeby był dobry (prawdziwy), musi być wiarygodny, natomiast film dokumentalny, którego wydarzenia są z gruntu prawdziwe, może być niewiarygodny, tak jak życie.

Kręcąc Pod ochrona, pokazywaliśmy bohaterów: matkę i syna uciekających przed przemocą ze strony męża/ojca. Przemocy nie pokazaliśmy bezpośrednio ani raz w filmie - takie było założenie konstrukcyjne, pomysł na fabułę - pokazywaliśmy fizyczne i psychologiczne konsekwencje, jakie wywołuje domowa przemoc. W tym celu wszystkie wydarzenia i sceny musiały nam w wiarygodny sposób pokazywać, że

\section{Wiarygodność czy prawda?}

[8] Rozmowa przeprowadzona przez autora z Jackiem Petryckim.

Il. 14. Argentyńska lekcja, reż. Wojciech Staroń 

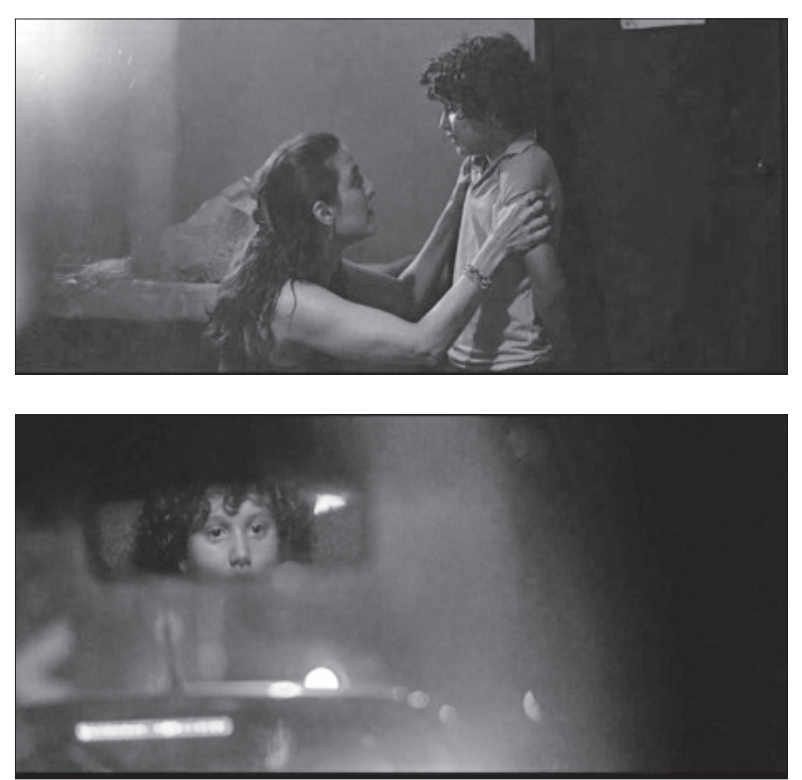

Il. 15. Pod ochrona, reż. Diego Lerman do przemocy faktycznie dochodziło, że strach jest prawdziwy, że jest przed czym uciekać. Ta decyzja na pewno wynikała z naszej „dokumentalnej przeszłości” - pokazujemy w filmie fabularnym świat z perspektywy bohatera, ale kamera nie jest wszechwiedząca, widzi tyle, ile on sam, a właściwie nawet tyle, ile mógłby zobaczyć operator, który kręciłby o nim film dokumentalny. W każdej scenie staraliśmy się odnaleźć ślady agresji, „uwiarygadniać” ją, by uzasadnić motywację do działań naszych postaci. Jeśli byśmy kręcili film dokumentalny $\mathrm{z}$ bohaterami w podobnym położeniu, byłoby prościej: nie musielibyśmy nic udowadniać, prawdopodobnie najciekawsze filmowo sytuacje opowiadałyby „przewrotnie” o rzeczach pozornie niezwiązanych z przemocą, ale widz i tak odczuwałby grozę prawdziwego położenia realnych bohaterów.

W moim filmie dokumentalnym Bracia jest scena, w której głównym bohaterom płonie dom, a w nim wszystkie obrazy, które jeden z nich malował przez całe życie. Dzieje się to dokładnie wtedy, gdy odnosi życiowy sukces - wyjeżdża na wymarzoną wystawę do Brukseli. Taki paradoks i zbieg okoliczności w filmie fabularnym byłby nie do zaakceptowania, czułoby się rękę scenarzysty, wyglądałoby to na wymyślone i niewiarygodne, wręcz kiczowate, ale w życiu i w filmie dokumentalnym - jest możliwe! Tym bardziej wstrząsające, mówiące o przeznaczeniu, o bezwzględności losu, o tym, jak wiele zawiłych dróg mamy przed sobą.

W książce Wojna nie ma nic z kobiety białoruska pisarka, dokumentalistka, laureatka Nagrody Nobla, Swietłana Aleksijewicz tak pisze o swoim warsztacie, o wydobywaniu autentyzmu i prawdy ze swoich bohaterów:

Szukałam długo... Jakimi słowami można przekazać to, co słyszę? Szukałam gatunku, który by odpowiadał temu, jak widzę świat; temu, jak zbudowane jest moje oko, moje ucho. [...] Z tego, co usłyszałam w dzieciństwie, z tego, co dzisiaj rozlega się na ulicy, w domu, w kawiarni, w trolejbusie tak! Krąg się zamknął. Znalazłam to, czego szukałam. [...] Przez dwa lata nie tyle spotykałam się i nagrywałam, ile rozmyślałam. Czytałam... O czym będzie moja książka? Długo siedzę w nieznajomym domu albo mieszkaniu, niekiedy cały dzień. Pijemy herbatę, przymierzam niedawno kupione bluzki, rozmawiam o fryzurach i przepisach kulinarnych. Oglądamy razem zdjęcia wnuków. No i wtedy... W końcu, nigdy nie wiadomo kiedy i dlaczego, nadchodzi długo oczekiwana chwila, gdy człowiek oddala się od kanonu - gipsowego czy żelbetowego, jak nasze pomniki - i wraca do siebie. Wchodzi w siebie. Zaczyna wspominać nie wojnę, ale swoją młodość. Kawałek własnego życia... Trzeba uchwycić tę chwilę, nie wolno jej przegapić! Tyle że często, po długim dniu wypełnionym słowami i faktami, pozostaje w pamięci tylko jedno zdanie, ale za to jakie!: „Poszłam 
na wojnę taka mała, że przez ten czas trochę urosłam”. To właśnie wpisuję do notatnika, chociaż mam nagrane dziesiątki metrów taśmy [...] Mniej ciekawi mnie to, co się dzieje, od tego, co się dzieje z uczuciami. Powiedzmy inaczej - od duszy wydarzenia. Dla mnie uczucia są rzeczywistością. A historia? Historia jest na ulicy... W tłumie...

Wierzę, że w każdym z nas tkwi fragment historii. U jednego pół strony, $\mathrm{u}$ innego parę stron. Razem piszemy księgę czasu, każdy wykrzykuje swoją prawdę. Trzeba tylko to wszystko usłyszeć, trzeba się w tym wszystkim rozpłynąć i tym wszystkim się stać. Pozostając zarazem sobą. Nie zniknąć[9].

Na planie fabularnym zazwyczaj w gruncie rzeczy chodzi o to samo, o co w dokumencie - o przekazanie informacji o pewnym zdarzeniu i o uchwycenie prawdy emocjonalnej postaci. Na jednym biegunie mamy ilustrację i informację, na drugim nastrój i emocje. Zachowanie właściwych proporcji między tymi dwoma składowymi jest niezbędne dla dobrej komunikacji z widzem i ostatecznie warunkiem stworzenia ciekawej opowieści. W przypadku dzieł wielkich mistrzów kina - Bergmana, Tarkowskiego, Kieślowskiego - zachwycamy się tym, że udało się twórcom sfotografować to, co jest niewidzialne: uczucia, nieproste emocje, wewnętrzny stan bohatera, przemianę - czyli to, co jest abstrakcją. Odbieramy to $\mathrm{z}$ drżeniem serca, ale trudno nam zrozumieć mechanizm działania owego „niewidzialnego". W czym tak naprawdę wyraża się abstrakcja? Z pomocą przychodzi mi Labirynt światła Jerzego Wójcika i jego pozornie proste stwierdzenie:

wszystko dzieje się zawsze za pomocą tego samego, za pomocą widzialności - i dodaje może ona opowiadać o sytuacjach, które są po prostu widoczne. Może też być widzialność, która opowiada o tym, co jest poza widzialnością, o pograniczu dwóch światów[10].

Filmowanie niewidzialnego jest obecne zarówno w filmie fabularnym, jak i dokumentalnym. W jaki sposób próbujemy owo „niewidzialne" uchwycić? Jak to konstruujemy?

Tarkowski jako przykład konstrukcji „niewidzialnego” podawał haiku. Krótka, bardzo wnikliwa obserwacja, która jest czymś więcej. Do pojęcia „niewidzialnego” znalazłem też bardzo dobre określenie u Tarkowskiego
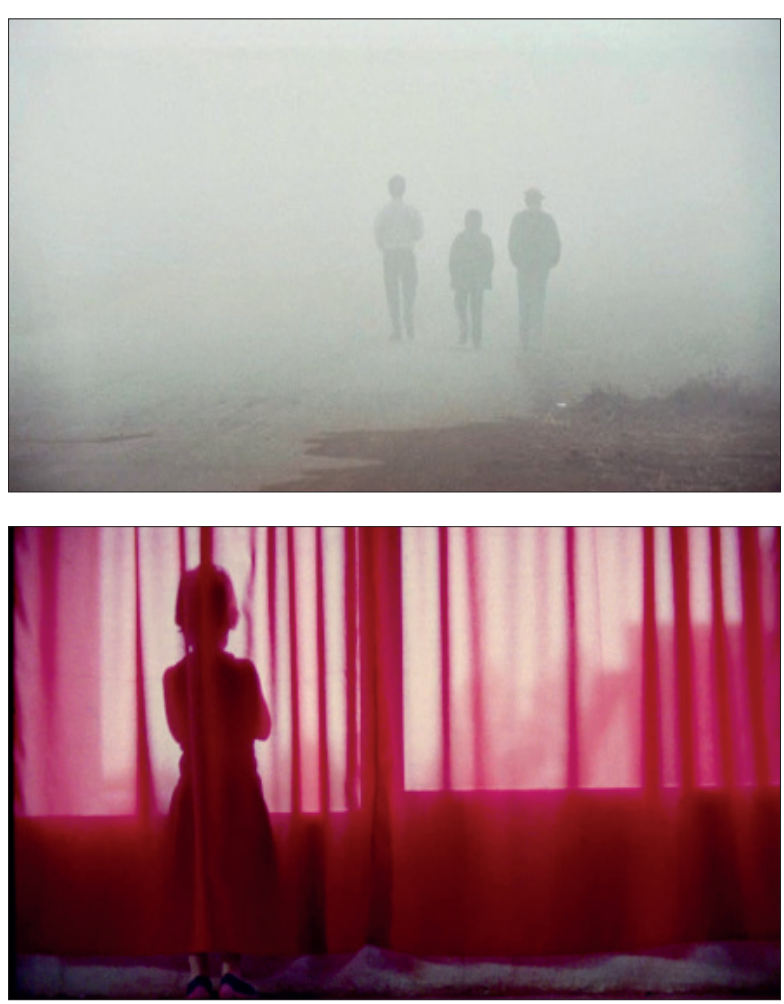
z japońskiego sabi, czyli naturalne rdzewienie, urok starego, pieczęć czasu, to ucieleśnienie związku sztuki i natury. Przez tak pojęty upływ czasu, zamknięty w rzeczy, przyrodzie,

\section{W poszukiwaniu niewidzialnego}

Il. 16. Argentyńska lekcja, reż. Wojciech Staroń 
można opowiedzieć (bez retrospekcji) o przeszłości, o tym, co kiedyś było - zauważyłem, że tak podświadomie budowałem cały kontekst społeczno-historyczny w Argentyńskiej lekcji: samochód, który Janek odkrywa u Marci, szyldy starych sklepów i opuszczone bary, kiedy Janek idzie do szkoły. W taki sposób opowiadałem o tym, jak to miasteczko wyglądało kiedyś, co pozostawili po sobie poprzednicy moich
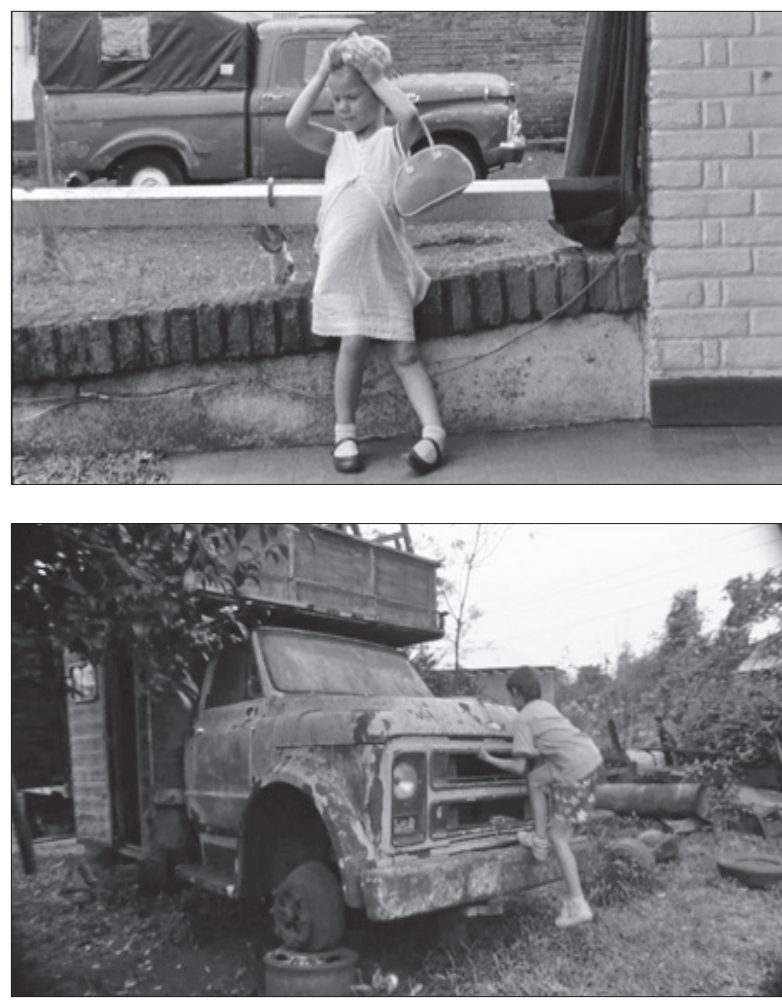
bohaterów. Wydaje mi się, że czas teraźniejszy, czyli filmowanie tu i teraz, świetnie mogą nam opowiedzieć o przeszłości, która tak naprawdę zarówno w życiu, jak i w filmie, jest iluzją. Ale nie można zapominać, że przeszłość zostawia ślady i te ślady powinny wypełniać nasze kadry, powinniśmy jako operatorzy tak patrzeć na rzeczywistość, by w tym, co widzialne teraz, dostrzegać czas przeszły, wybierać takie obiekty i tak je filmować, by budować pozakadrową przestrzeń czasu.

Czas jest niezwykle subiektywnym odczuciem, jest abstrakcyjny, jest przestrzenią, w której styka się realność i iluzja, film jest więc najwierniejszym jego sprzymierzeńcem, jego „utrwalaczem”. W filmie możemy, a nawet musimy tworzyć własny czas i to jest niezwykle ekscytujące. W dwóch godzinach projekcji zamykamy nieskończoną ilość czasu.

O sposobie wyrażania „niewidzialnego" chciałem opowiedzieć na przykładzie Pod ochrona. Interesujące jest tam to, że przez cały

Il. 17. Argentyńska lekcja, reż. Wojciech Staroń film nie widzimy ojca głównego bohatera, nie widzimy bezpośrednio źródła zła. A pomimo to film ma staranną konstrukcję dreszczowca. Jak budować zagrożenie, lęk, obawę bez ukazania źródła problemu? Jak rejestrować stany wewnętrzne bohaterów, przekazywać bodźce pozawerbalne, nieliterackie, abstrakcyjne? magisterska: Archiwum PWSFTviT w Łodzi)

Wójcik J., Labirynt światła, Warszawa 2006 